\title{
Fifty years of oomycetes-from consolidation to evolutionary and genomic exploration
}

\author{
C. André Lévesque
}

Received: 5 July 2011 / Accepted: 26 July 2011 /Published online: 13 August 2011

(C) Her Majesty the Queen in Right of Canada, as represented by the Minister of Agriculture and Agri-Food Canada 2011

\begin{abstract}
Transformative changes in biological sciences during the past 25 years have led to many significant advances in oomycete research. Before the last half century there were some hints that the oomycetes were related to some algae but it is now definitively demonstrated that they do not share an evolutionary path with kingdom Eumycota and are instead placed in a new kingdom Straminipila. Clarifying this once and for all has created many opportunities, but the rapid expansion of the research community has caused some fragmentation, probably much more so than in other groups of fungi because of a lack of a unifying forum for the members of the community working on issues such as taxonomy or phylogeny. Prior to the advent of molecular phylogenetics, mycologists working in zoosporic fungi were examining the ultrastructure of the zoospore, mainly focussing on the flagellar apparatus, and managed to generate phylogenies or define clades of zoospore producing fungi that remained for the most part valid after the advances in molecular biology. Comprehensive molecular phylogenies that have been published for some genera of the oomycetes have helped in recognising a large number of new species and in the development of a wide range of DNA-based diagnostic tools. The number of genomes available for this group is increasing rapidly, pushing further the discoveries of novel host-parasite interaction mechanisms in oomycetes. Some important plant diseases that were believed to be under control have re-emerged and many new diseases have appeared particularly in forestry and even in mammals. The research community
\end{abstract}

C. A. Lévesque $(\bowtie)$

Central Experimental Farm, Agriculture and Agri-Food Canada, Ottawa, Ontario, Canada K1A 0C6

e-mail: andre.levesque@agr.gc.ca has been able to respond rapidly and effectively to these new challenges. New ecological roles for the oomycetes were found in the suppression of plant diseases and reduction of plant invasineness in natural ecosystems. There are still many challenges ahead in the oomycete community, probably the most pressing one is to establish a robust tree of life foundation like the Assembling the Fungal Tree of Life initiative. The oomycete research community is dynamic and has put to very good use the many new technological advances.

Keywords Oomycetes $\cdot$ Oomycota $\cdot$ Peronosporomycetes

\section{Introduction}

The past 50 years is a period that was influenced by transformative changes in the life sciences, particularly in the past 25 years, which had a profound impact on the oomycete research community. The title of this paper was inspired by Clive Brasier $(2009,2008)$ who made a similar statement regarding the biosystematics of Phytophthora species which I believe describes well many of the research and developments trends in the oomycetes as a whole. The estimated number of oomycete species is relatively small when compared to other fungal taxonomic groups and in the middle of the 20th century, there was some consolidation in many of the taxonomic groups. With the advent of recombinant DNA technology a new era began in classification, biodiversity discovery and the study of oomycete biology in general. This historical overview will focus primarily on oomycete biodiversity, systematics and phylogenetics. Other aspects of research on oomycetes will also be covered, only briefly though because so much work has been achieved in the last half century. 
Fifty years ago, the oomycetes were defined as "phycomycetes having oospores" and the Phycomycetes were at the same classification level as the ascomycetes and basidiomycetes within the Fungi (Ainsworth 1961). In the latest edition of the dictionary of fungi, omycetes are defined as a class within the kingdom Chromista (Kirk et al. 2008). The name oomycetes (Winter 1880) and its associated formal name Oomycota (Arx 1967) will be used throughout this chapter. An alternative group name, the Peronosporomycetes, was formally proposed by Dick (2001) and is here considered a synonym as in Kirk et al. (2008). The name change to Peronosporomycete was proposed because of an overly strict interpretation of the International Code of Botanical Nomenclature. The requirement that a generic name be embedded into the higher order name is only applied to a family rank and its typification, the rules of nomenclature above the family level are not so strict. The etymological root of Oomycota refers to the presence of egg-like structures which is certainly an appropriate descriptive name for the organisms this higher level name represents. The taxonomic rank of Oomycota varies from class to phylum and I believe that the latter, or at least a subphylum rank, would simplify and streamline the much needed reclassification within this group.

\section{The great schism}

Pringsheim (1858) recognized over 150 years ago that the oomycete reproductive structures showed similarities to those of the yellow-green alga Vaucheria. Bessey (1942) also recognised some problems with the existing classification of oomycetes. During the past 50 years, the biochemical and morphological evidences of a misinterpration of the evolutionary relationship of the oomycetes and fungi grew steadily and rapidly. Differences in biochemical pathways were identified (Vogel 1960, 1961; LéJohn 1971). Bartnicki-Garcia $(1966,1968,1969)$ demonstrated that the cell wall composition of oomycetes was primarily made of glucans and cellulose as opposed to chitins and Parker et al. (1963) showed similarities in cell wall composition with the Vaucheriaceae. Cavalier-Smith $(1981,1987)$ recognised and stipulated that oomycetes along with labyrinthulids, thraustochytrids, and hyphochytrids should no longer be viewed as true Fungi and be placed instead within a group he called pseudofungi, alongside the diatoms and brown algae, in the kingdom he defined as Chromista (Cavalier-Smith 1986). The final evidence that settled the ongoing controversy came from molecular phylogenetic analyses. Gunderson et al. (1987) demonstrated that Achlya and the brown alga Ochromonas were closely related when compared to organisms from several kingdoms. The small subunit (SSU) ribosomal DNA sequences showed that the genetic distance between Achlya bisexualis and Ochromonas danica was equal to the distance between Saccharomyces cerevisiae and Neurospora crassa. Using this same gene region, Förster et al. (1990) demonstrated that a zoosporic chytridiomycete was grouped with the true Fungi whereas Phytophthora species were grouped with the previously sequenced Achlya. The argument of whether or not the oomycetes were monophyletic with the true Fungi was over. It has been proposed and widely accepted that oomycetes should still be considered fungi as they share many functional characteristics such as modes of nutrient absorption and growth habit with the true Fungi (Money 1998). Using small "f" on the word fungi is a practical solution when we want to speak about an inclusive functional group (Dick 2001). The phylum Pseudofungi is now narrowed down to a monophyletic clade containing oomycetes, hyphophytrids and Pirsonia (Cavalier-Smith and Chao 2006) and no longer includes all the straminipilous fungi (Tsui et al. 2009), therefore, pseudofungi is not a useful colloquial name for mycologists. Oomycetes, other straminipilous fungi and some other non-photosynthetic osmotrophs are still included in mycology textbooks although they are now listed in a separate section of the dictionary of the fungi as chromistan or protozoan fungal analogues (Kirk et al. 2008). This change in "phylogenetic affiliation" from the well established mycological community originally organized under a kingdom to a new and very broad kingdom had a profound impact on the association and organization of the members of the oomycete community.

The fragmentation of science into more specialized areas has been a general trend over the past 50 years, however, this effect was probably more pronounced in the oomycete community because this taxonomic group is no longer part of the monophyletic Eumycota of mycology. At the first International Mycological Congress (IMC) of 1971, 6\% of the 392 presentations were oomycete based whereas only $0.6 \%$ of the 315 presentations and $1.4 \%$ of the more than 1133 posters were on oomycetes at IMC9 in 2010. Many of the research areas covered in the subsections of this chapter are now well represented by specialized scientific societies with annual meetings where there is a significant number of contributions on oomycetes. For example, at the annual meetings of the American Phytopathological Society, the number of presentations and posters related to oomycetes went from $3.5 \%$ out of 230 in 1971 to $13 \%$ out of 878 in 2010. Attendance at mycology meetings would tend to demonstrate that the oomycete community has been shrinking when attendance at some other scientific meetings shows the opposite trend.

The movement of the oomycetes to another kingdom created challenges in generating an appropriate name for the kingdom. The phycological kingdom name Chromista 
excludes the colourless oomycetes, labyrinthulids, thraustochytrids or hyphochytrids that are well embedded within a large monophyletic group mostly with photosynthetic organelles. Patterson (1989) proposed, the stramenopiles, as an inclusive name describing the appearance of the tubular hairs on flagella as "straw with hairs". This taxonomic concept whereby the unifying structures are the flagellar hairs, is broader and more appropriate for the oomycetes and their related groups. The first proposal for stramenopiles was not formally presented as a kingdom but Dick (2001) did propose that the name kingdom Straminipila be applied. Unfortunately, there has been a fairly significant amount of confusion in the correct spelling of this name. There have been numerous combinations of vowels applied in the name as well as the incorrect usage of the suffix "philes" instead of "piles" (Table 1). This becomes a serious impediment in this day and age of digital document searches. This is an example where having a community clearly unified under one international scientific society would help settle these technical issues by consensus or votes. However, the current usage trend should be an acceptable situation for a majority rule decision. The original colloquial name "stramenopiles" as proposed by Patterson (1989) and currently used by the NCBI taxonomy is by far the most commonly used term. The more formal kingdom name Straminipila given by Dick (2001) and its derived adjective straminipilous are together the second most commonly used names.

Table 1 Google hits (June 2011) of different spelling for the stramenopile group of organisms first proposed by Patterson (1989)

\begin{tabular}{lr}
\hline Name searched & Number of hits \\
\hline Stramenopile(s) & 187,000 \\
Straminipila & 15,990 \\
Straminipilous & 54,600 \\
Stramenopila & 24,600 \\
Straminipile(s) & 9,410 \\
Stramenophile(s) & 6,360 \\
Straminopile(s) & 3,040 \\
Stramenophila & 2,740 \\
Straminopila & 1,320 \\
Straminopilous & 696 \\
Stramenopilous & 108 \\
Stremenopile(s) & 51 \\
Stramenipile(s) & 4 \\
Stramenipilous & 3 \\
Straminiphila & 3 \\
Straminophila & 3 \\
\hline
\end{tabular}

${ }^{\mathrm{a}}$ with or without capital letters and total number of hits for singular or plural names

\section{Ultrastructure of the zoospore}

The oomycete community has been proactive in making judicious usage of technological advances that can help answer important questions, regardless of the challenges that needed to be overcome to adapt the technology to oomycetes. The usage of transmission electron microscopy to look at the ultrastructure of motile zoospores is an excellent example of a challenging technological advance. The development of this technique was done with the chytrids (Barr and Hartmann 1976; Chong and Barr 1973). The first detailed study of the ultrastructure of the flagellar apparatus of oomycete zoospores was performed by Holloway and Heath (1977). Additional species of oomycetes, hyphochytrids and thraustochytrids were studied by Barr and Allan (1985). The main features of the apparatus are the two different flagella, the basal bodies or kinetosomes, a transitional zone between these regions, and the roots which anchor the flagella. Within this apparatus defined by regions, there are conserved and more variable areas such as the flagellar roots. This provides an ideal situation to generate phylogenies based on morphology at various taxonomic depths and to determine if groups of organisms are monophyletic. The transitional zone ultrastructure has morphological differences that clearly separate the chytrids, the oomycetes and green algae or plants (Barr 1992). A comprehensive multigene phylogeny of the oomycetes is not available yet and the painful reconstruction of the zoospore ultrastructure remains to be done for several oomycetes genera. However, absence of hairs on the anterior flagellum has been reported on many of the basal genera whereas differences K-bodies and vesicles are found among higher orders (Beakes et al. 2011; Beakes 1987). Several important morphological structures used in taxonomic keys that are easily observable by light microscopy are known to be polyphyletic characters, e.g. ornamentation of oospores, and are of little use for phylogeny. On the other hand, phylogenies based on zoospore ultrastructure features such as the helix of the transitional zone or the base and root of the flagella remained for the most part valid following the advent of molecular phylogenies. Unfortunately, the technical complexity of doing transmission electron microscopy combined with the difficulties in obtaining the proper sections of zoospores is discouraging many to pursue this line of work.

\section{DNA technology}

The pioneers in oomycete research

DNA was discovered in 1953 but it is in the 1970's that this discovery started to be exploited in oomycete research. 
Green and Dick (1972) determined by $\mathrm{CsCl}$ gradient untracentrifugation the percent $\mathrm{GC}$ composition and the presence of satellite bands for various Saprolegniaceae. With the advent of recombinant DNA technology in the 1970's it was now possible to transform an organism with DNA from another species using a range of molecular biology protocols such as DNA digestion by restriction enzymes, electrophoresis, DNA hybridization, that had all been adapted to work with minute amounts of DNA. It started to be exploited by scientists working on oomycetes in the 1980's. The impact of the work by Gunderson et al. (1987) and Förster et al. (1990) on the classification of the oomycete at the kingdom level was mentioned above. Klassen et al. (1987) used differential DNA extraction with $\mathrm{CsCl}$ centrifugation to generate restriction maps of rDNA. Panabières et al. (1989) looked at restriction fragment length polymorphism (RFLP) of total DNA, Förster et al. (1989) and Martin and Kistler (1990) looked at RFLP of purified mitochondrial DNA to compare Phytophthora species whereas Martin (1991) characterized the circular plasmid in three Pythium spp. Goodwin et al. $(1989,1990$ a, b) generated species specific cloned DNA probes to detect Phytophthora species by hybridization. Hulbert et al. (1988) developed a genetic map of Bremia lectucae by RFLP whereas Judelson and Michelmore (1989, 1990) studied its gene expression and identified promoters that Judelson et al. (1991) used to generate a hygromycin resistant $P$. infestans strain. Mao and Tyler (1991) characterized the size and the general organization of the P. sojae genome. During the 1990 's, transformative molecular biology technologies, especially the polymerase chain reaction (Mullis and Faloona 1987), became more widespread in oomycete research and were the basis for a broad range of applications.

\section{Molecular phylogeny}

With universal primers developed for fungi that also worked for oomycetes (White et al. 1990) and a significant number of rDNA sequences available for designing more primers it was possible to generate sequences for rDNA for a wide range of genera within the oomycetes. Briard et al. (1995) generated partial sequences of the large nuclear ribosomal subunit (LSU) for some of Pythium and Phytophthora species. Dick et al. (1999) sequenced the complete SSU from eight different genera of oomycetes. Riethmüller et al. (1999) sequenced the D1 and part of the D2 region of LSU for close to 50 species in several oomycete genera, Petersen and Rosendahl (2000) did 24 species among five orders with the same sequence region whereas Leclerc et al. (2000) looked at LSU and ITS in a study on Saprolegniaceae. Hudspeth et al. (2000) performed partial sequencing of the mitochondrial cytochrome oxydase 2 gene that included 15 genera of Oomycetes. As was mentioned above, the concept of a monophyletic group for the oomycetes clearly separated from the true Fungi had emerged and these studies supported the monophyly of oomycetes. Sparrow (1976) proposed the concept of two galaxies within the oomycetes which was formalized by Dick (2001) as the subclasses Saprolegniomycetidae and Peronosporomycetidae. An important advance in oomycete phylogenetics was to demonstrate that Eurychasma is the most basal clade identified to date (Sekimoto et al. 2008a; Kuepper et al. 2006). The evolutionary origin of the oomycetes is currently believed to be in the sea as obligate parasites with saprophytism on land as the derived state (Beakes et al. 2011). The peronosporalean galaxy appears to be monophyletic with the limited number of markers we have so far whereas the saprolegnian galaxy is no longer considered monophyletic once the additional more basal taxa were included (Beakes et al. 2011).

In the oomycetes, there have been very comprehensive phylogenies done at the genus level. Lee and Taylor (1992) generated a phylogeny for five Phytophthora species based on ITS whereas Cooke et al. (2000) produced a phylogeny for all the Phytophthora species known at the time. Lévesque and de Cock (2004) completed an equivalent study with all available Pythium species. Multigene phylogenies with very comprehensive sets of species were also completed for Phytophthora (Blair et al. 2008; Kroon et al. 2004). These studies among many others such as the work of Voglmayr (2003) on Peronospora provided insight into the phylogeny within selected genera but also paved the way to routine use of DNA sequencing to identify strains and specimens. This "DNA barcode" approach to identification is most robust when comprehensive and accurate databases exist. GenBank does provide the keyword "barcode" to entries that do fit certain criteria, namely, reference to vouchers such as type specimens or ex-type strains, electropherograms to assess sequence quality, and the use of one of their recognized marker for DNA barcoding. The cytochrome oxidase 1 (COI) is the default DNA barcode in GenBank and it does work to identify Phytophthora species (Martin and Tooley 2003). An extensive database with ca. 1,200 strains was recently produced to confirm that $\mathrm{COI}$ is appropriate to identify oomycetes but that the ITS de facto barcode works as well (Robideau et al. 2011). The formal addition of ITS as barcode for oomycetes in GenBank has been proposed.

New species discovery

Species continue to evolve and where to draw the line that separates two species within a large population is not a trivial task even in this day and age of molecular systematics. A better understanding of centers of origin 
and species boundaries goes hand in hand with improved population genetics tools leading to a better understanding of genetic diversity, gene flow, and the speciation process. Advances specific to population genetics will be covered later when discussing some economically important pathogens. There have been some very significant studies, monographs and keys that have consolidated the status of taxonomic knowledge in important genera prior to the advent of molecular phylogenetics (Seymour 1970; Dick 1990; van der Plaats-Niterink 1981; Waterhouse 1967, 1963; Erwin and Ribeiro 1996; Newhook et al. 1978). Historically, new species have been mainly described by specialized taxonomists and the publications of new monographs were often accompanied by a spike in new species description. Figure 1 shows a very sudden increase in the number of species of Peronospora in 1923 (Gäumann 1923) and a smaller increase for Saprolegnia in 1970 (Seymour 1970). Since 2000, the increases in new species description for Phytophthora and Pythium have been exponential and driven by many different scientists, most of them not trained as taxonomists. It has even led to the discovery of new related families and genera (Hulvey et al.
2010). This is a very significant departure from the past. This democratization of taxonomy is a positive step, especially with so many undescribed species present in the world that need to be documented, however, good science should prevail and describing a new species with a single strain that has a few base pair differences in its ITS sequence compared to an ex-type should be avoided. Spies et al. (2011) clearly demonstrated that there is gene flow among some of the newly described species within the Pythium irregulare complex. If molecular phylogeny becomes the new approach to define new species, the phylogenetic species concept based on multiple gene phylogeny should be applied (Taylor et al. 2000).

Diagnostics and molecular detection

The oomycetes can be challenging to isolate or identify and there are many instances where differentiating the economically important species, which are often also quarantine pathogens, from the ubiquitous and innocuous ones is very difficult. Antibody technologies provide cheap and user friendly diagnostic tools and are still used extensively in
Fig. 1 Total number of species over the years for different genera of oomycetes. Species names and years based on data in Mycobank

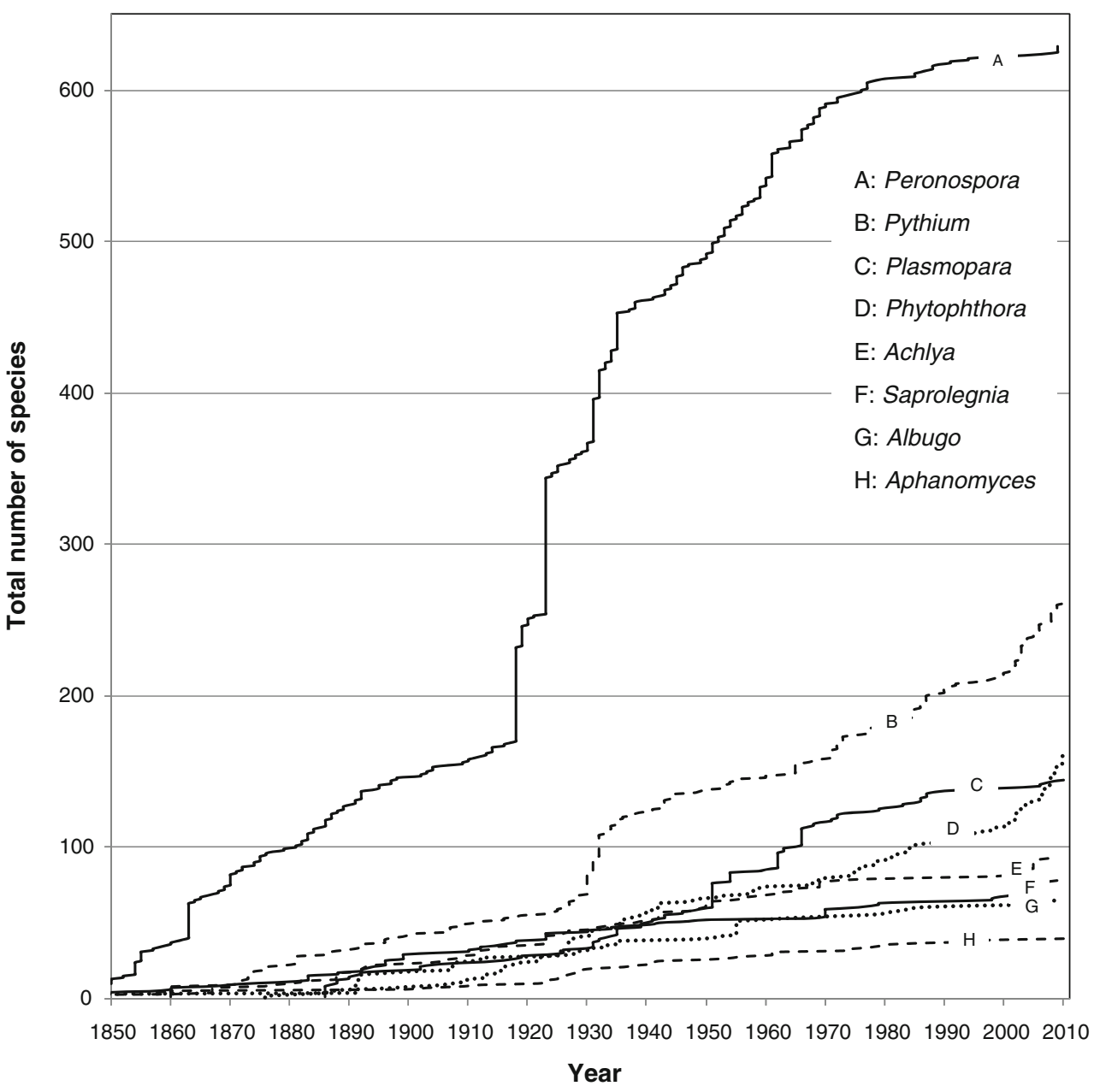


virology and bacteriology. In mycology such technology has been rarely developed for diagnostics but they have been used in oomycetes (e.g. Kox et al. 2007; Cahill and Hardham 1994). As mentioned above, DNA sequence databases are quite comprehensive for some genera of oomycetes and polymorphisms have been exploited extensively to develop DNA-based molecular assays. A comprehensive certification system for Phytophthora fragariae in strawberry was one of the early ones developed and was discussed as a case study in Martin et al. (2000). Many PCR assays were developed for P. ramorum (e.g. Tomlinson et al. 2007; Bilodeau et al. 2007; Tooley et al. 2006; Martin et al. 2004; Hughes et al. 2006; Hayden et al. 2006), to the point of causing some confusion in the international regulatory community as to which one should be routinely used. The international ring trial to evaluate several of these methods simultaneously with the same samples should become a model for other pathogens (Martin et al. 2009). The first DNA array system in mycology or plant pathology was developed for oomycetes (Lévesque et al. 1998) and an array with all known species of Pythium was developed for direct detection in soil (Tambong et al. 2006). The lab-on-achip is the Holy Grail in diagnostics and such a device was recently developed for selected Phytophthora species (Julich et al. 2011), showing again that there is leardership in the oomycete scientific community.

The cloned and sequenced PCR products obtained directly from soil using oomycete-specific primers showed a wide range of unidentifiable sequences because they were either new species or known species without LSU sequences in GenBank (Arcate et al. 2006). This kind of work used to be very time consuming. There is no doubt that there will be a rapidly increasing number of environmental sequences obtained by using the next generations of sequencing technologies such as pyrosequencing which no longer require cloning before sequencing. Having reliable and comprehensive reference sequence databases for these markers will be more important than ever.

\section{Genomics}

Oomycete researchers have been at the forefront of plant microbe interactions and the spectacular advances in oomycete genetics and genomics are well covered in a recent book (Lamour and Kamoun 2009) whereas some of the early work in recombinant DNA technology was mentioned above. The well known hypersensitive response in host parasite interaction has been attributed to the interaction between avirulence and resistance genes (Kamoun et al. 1999; Rehmany et al. 2005; Allen et al. 2004). Amino acid signature motifs (RXLR-dEER) were identified in the first oomycete avirulence genes discovered (Birch et al. 2006; Tyler et al. 2006) which were demonstrated to be translocation signals to move these associated proteins into plant cells (Whisson et al. 2007). The complete genome sequences are now available for three Phytophthora species (Haas et al. 2009; Tyler et al. 2006), for Pythium ultimum (Lévesque et al. 2010) and Hyaloperonospora arabidopsidis (Baxter et al. 2010). The RXLR effectors are very common in Phytophthora and Hyaloperonospora but are absent in Pythium ultimum. Many more genome sequences will become available and we are now reaching a new level of understanding of how species differ from each other.

\section{Oomycetes as pathogens}

Oomycetes pathogens are found on all crops and in many aquatic or terrestrial plants as well as in many animals. All the different impacts of oomycetes as plant or animal pathogens cannot be covered here but a few significant examples deserve to be discussed.

The re-emergence of a disease

The most famous, or maybe infamous, oomycete is Phytophthora infestans, the species that caused the Irish potato famine in the 1800 's. Until the 1980 's, only a single clonal lineage of the A1 mating type was present outside Mexico or the Andes (Goodwin et al. 1994), the centre of origin being still debated (Grunwald and Flier 2005; Gomez-Alpizar et al. 2007), and after that the A2 mating type was introduced to both Europe and North America. This caused $P$. infestans to re-emerge as a very serious threat to potato cultivation by increasing its aggressiveness towards the host, reducing fungicide efficacy, facilitating its survival in soil or debris and broadening its host range to include tomato (Fry et al. 1992; Fry and Goodwin 1997; Gavino et al. 2000; Lee et al. 1999). Because of the significant impact of this migration, $P$. infestans has become a model system for population genetics and the basis of international collaborations for population tracking (Cooke and Lees 2004; Goodwin et al. 1992; Forbes et al. 1998; Fry et al. 1992).

\section{Forestry}

Fifty years ago, the number of known species of oomycetes having an impact on forestry was quite low. Phytophthora cinnamomi and $P$. cambivora were the most notable disease agents (Brasier 2000). More recently the impact of oomycetes on forestry has increased dramatically with wider ranges of known diseases and more importantly the emergence of agents that were not previously known. Prior to 2000 , only $20 \%$ of Phytophthora species were known to 
have an impact in forestry whereas $60 \%$ of the species described since that time are associated with forestry or natural environments (Brasier 2009). This exponential growth post 2000 is mainly due to new species of Phytophthora being described that are associated with forestry (Fig. 1) and there has been an increased interest in Phytophthora in forest environments that might be partly responsible for this sudden increased diversity. As an example, the working group "Phytophthora diseases on forest trees" (7.02.09) is one of the most active within the subdivision Pathology of the International Union of Forest Research Organizations (IUFRO). They have organized five major symposia since 1999 .

The emergence of Phytophthora ramorum is an important example of the impact that Phytophthora has had on the nursery trade and forestry. This species was first described in Europe as the causal agent of a foliar and twig disease of Rhododendron (Werres et al. 2001). Starting in the mid 1990's, "sudden oak death" disease was devastating the forests of central California. Sudden oak death was then proven to be caused by the same species that was causing disease on Rhododendrons in Europe (Rizzo et al. 2002). In one decade there were hundreds of scientific publications and many popular press articles focused on P. ramorum. A lot of confusion and potential trade issues were avoided by immediately linking the seemingly separate outbreaks in Europe and California. This shows again the very practical and economical relevance of having an accurate Latin binomial system and how important it is to agree on species names internationally. With the availability of DNA sequence searches by BLAST, putative new species from different parts of the world can be linked together even before new species are described if the sequences are available. In forestry, some of the new causal agents belonging to Phytophthora are hybrids (e.g. Brasier et al. 1999) and molecular taxonomy has contributed greatly to characterizing these strains quickly and unambiguously. In P. ramorum, the need to globally agree on names at a finer resolution level than the species is also important and there has been a concerted effort to standardize the nomenclature of its clonal lineages (Grünwald et al. 2009).

\section{Mammalian pathogen}

Aphanomyces, Lagenidium or Myzocytium have been well known to parasitize invertebrates and the impact of oomycetes as fish parasites has also been significant. Pythium insidiosum was first described as the causal agent of mycoses in horses, dogs and cattle (De Cock et al. 1987). Reports of such diseases were noted over 100 years earlier and the only association with a possible oomycete causal agent were the reports of aseptate hyphae in the skin. $P$. insidiosum infections have since been reported in humans and can be the cause of either superficial or deeper systemic infections (Mendoza 2009). These infections have been observed in many countries but are most prevalent in Thailand. The mode of infection is through zoospores and typically occurs through the skin immersed in water. However the human eye is itself a "micro" aquatic environment and infections of the cornea have been reported (Thomas 2003). P. insidiosum is a monophyletic complex that may require to be described as a few different species (Schurko et al. 2003). Comparing the pathogenicity mechanisms of $P$. insidiosum with plant pathogens would be very interesting and the absence of a fully sequenced genome for this species is a major gap in our knowledge of oomycetes.

\section{The hidden plant diseases}

The economic impact of root rot diseases has always been hard to evaluate especially in field crop or forestry because it is difficult to perform large scale yet controlled experiments. The advent of selective systemic fungicides to control root diseases and technologies to apply fumigants on a large scale provided some options to investigate these diseases. It was demonstrated that reducing Pythium in soil was constantly associated with significant yield increases of wheat in the Pacific Northwest (Cook et al. 1987) and that the oomycete-specific fungicide metalaxyl increased the yield of various field crops in Australia despite not being effective against all species of Pythium (Harvey and Lawrence 2008). The economic impact of endemic oomycetes that are always present and that are continuously causing some yield reductions remains to be determined.

\section{Ecology}

\section{Biological control}

Biological control of plant diseases has become a significant management option over the past 50 years and many studies have focussed on the management of oomycete diseases (e.g. Nelson et al. 1988; Paulitz and Bélanger 2001). The biological control agents P. oligandrum (Vesely 1977) and P. nunn (Lifshitz et al. 1984) were discovered and have been shown to control Pythium diseases (Martin and Loper 1999). This is a rare situation in biological control in that the control agent is from the same genus as the pathogen or pest it is controlling. The antagonistic action of $P$. oligandrum was shown to be through mycoparasitism and antibiosis against plant pathogenic Pythium species (Benhamou et al. 1999) but also through direct induction of systemic acquired resistance in the host 
plant (Benhamou et al. 2001). Hopefully the genome of $P$. oligandrum will be sequenced soon to provide insight into this species with very unique three way biocontrol-agent/ host/pathogen interactions.

A new role for "plant pathogens"

It is hard to loose the anthropomorphic angle in science and this is particularly true for organisms that cause diseases. Packer and Clay (2000) caused a major paradigm shift by demonstrating that a Pythium sp. colonizing mature black cherry trees (Prunus serotina) is actually reducing intraspecific competition by killing cherry seedlings growing under the canopy. They further demonstrated the importance of Pythium in this system by showing that the presence of some species was necessary to reduce the invasiveness of this plant species (Reinhart et al. 2010) and that their absence in Europe was the main reason for high density growth and invasiveness of $P$. serotina. The Pythium sp. from Packer and Clay (2000) was subsequently described as the new species $P$. attrantheridium (Allain-Boulé et al. 2004) which had been extensively isolated from apple trees suffering from apple replant problem. Some Pythium species appear to have evolved to colonize the roots of mature trees to prevent the establishment of young trees of the same species under the canopy. In such natural system, it would be beneficial to the well established trees to maintain a certain level of root colonization by rather weak root pathogen that are more aggressive on seedlings or young plants. However, in a horticulture or sylviculture situation where mature trees are removed or harvested to be replaced by young saplings, this could lead to a significant replant problem.

\section{Conclusion}

The oomycete community desperately needs an initiative such as the Assembling the Tree of Life (AFTOL) which served to really unify mycologists from a wide range of expertise. One of the unexpected side effects of the fact that many mycologists working on oomycetes are no longer interacting with mycological societies has been the deepening of the split between the marine/aquatic and terrestrial scientific communities. The major oomycete symposia and workshops that are now found at phytopathological meetings such as the International Congress of Plant Pathology or the American Phytopathological Society do focus on terrestrial and plant pathogenic species. Saprophytic growth in oomycetes appears to have derived from simple holocarpic parasites living in the ocean (Beakes et al. 2011). In order to generate a complete phylogeny of oomycetes and truly understand their evolution, a better coverage of obligate parasites from less well known environments and hosts will be needed (e.g. Sekimoto et al. 2008b). Even for the obligate parasites of plants such as the downy mildews, advances are being made (e.g. Thines et al. 2008) but a major effort will be required to generate molecular data for many of the described species that are in herbaria. As we are working at building up a robust tree of life for oomycetes and as we are sequencing multiple markers for an increasing number of taxa, it is becoming apparent that some well known and economically important genera are polyphyletic (e.g. Riethmüller et al. 2002). We should refrain from sweeping reorganization of the oomycetes and their genera, particularly when many practitioners are routinely using the names for their work, until we have a more robust multigene phylogenetic framework.

There is no doubt that molecular biology will continue to play a leading role with the advent of technologies like single DNA molecule sequencing which should provide complete genome sequences at what used to be the cost to sequence a few genes. Single molecule DNA sequencing might help to solve the issue of obtaining sequence data from type specimens. These advances will be beneficial to all mycologists but in order to make the most effective use of the new technology and data for understanding better evolution and biodiversity, researcher working on oomycetes will need to interact among themselves better than they have done in the recent past.

Acknowledgements I want to thank Tara Rintoul and two anonymous reviewers for a critical revision and editing of the manuscript.

\section{References}

Ainsworth GC (1961) Ainsworth \& Bisby's dictionary of the fungi, 5th edn. Commonwealth Mycological Institute, Kew

Allain-Boulé N, Tweddell R, Mazzola M, Bélanger R, Lévesque CA (2004) Pythium attrantheridium sp. nov. - taxonomy and comparison with related species. Mycol Res 108:795-805

Allen RL, Bittner-Eddy PD, Grenville-Briggs LJ, Meitz JC, Rehmany AP, Rose LE, Beynon JL (2004) Host-parasite coevolutionary conflict between Arabidopsis and downy mildew. Science 306:1957-1960. doi:10.1126/science.1104022

Arcate JM, Karp MA, Nelson EB (2006) Diversity of Peronosporomycete (oomycete) communities associated with the rhizosphere of different plant species. Microb Ecol 51:36-50

Arx JAv (1967) Pilzkunde. J. Cramer, Lehre

Barr DJS (1992) Evolution and kingdoms of organisms from the perspective of a mycologist. Mycologia 84:1-11

Barr DJS, Allan PME (1985) A comparison of the flagellar apparatus in Phytophthora, Saprolegnia, Thraustochytrium and Rhizidiomyces. Can J Bot 63:138-154

Barr DJS, Hartmann VE (1976) Zoospore ultrastructure of 3 Chytridium spp. and Rhizoclosmatium globosum. Can J Bot 54:2000-2013

Bartnicki-Garcia S (1966) Chemistry of hyphal walls of Phytophthora. J Gen Microbiol 42:57-69 
Bartnicki-Garcia S (1968) Cell wall chemistry, morphogenesis, and taxonomy of fungi. Annu Rev Microbiol 22:87-108

Bartnicki-Garcia S (1969) Cell wall differentiation in the phycomycetes. Phytopathology 59:1065-1071

Baxter L, Tripathy S, Ishaque N, Boot N, Cabral A, Kemen E, Thines M, Ah-Fong A, Anderson R, Badejoko W, Bittner-Eddy P, Boore JL, Chibucos MC, Coates M, Dehal P, Delehaunty K, Dong S, Downton P, Dumas B, Fabro G, Fronick C, Fuerstenberg SI, Fulton L, Gaulin E, Govers F, Hughes L, Humphray S, Jiang RH, Judelson H, Kamoun S, Kyung K, Meijer H, Minx P, Morris P, Nelson J, Phuntumart V, Qutob D, Rehmany A, Rougon-Cardoso A, Ryden P, Torto-Alalibo T, Studholme D, Wang Y, Win J, Wood J, Clifton SW, Rogers J, Van den Ackerveken G, Jones JD, McDowell JM, Beynon J, Tyler BM (2010) Signatures of adaptation to obligate biotrophy in the Hyaloperonospora arabidopsidis genome. Science (New York, NY) 330:1549-1551

Beakes GW (1987) Oomycete phylogeny: ultrastructural perspectives. In: Rayner ADM, Brasier CM, Moore D (eds) Evolutionary biology of the fungi. Cambridge University Press, Cambridge, pp 405-421

Beakes G, Glockling S, Sekimoto S (2011) The evolutionary phylogeny of the oomycete "fungi". Protoplasma 1-17. doi:10.1007/s00709-011-0269-2

Benhamou N, Rey P, Picard K, Tirilly Y (1999) Ultrastructural and cytochemical aspects of the interaction between the mycoparasite Pythium oligandrum and soilborne plant pathogens. Phytopathology 89:506-517. doi:10.1094/PHYTO.1999.89.6.506

Benhamou N, Bélanger RR, Rey P, Tirilly Y (2001) Oligandrin, the elicitin-like protein produced by the mycoparasite Pythium oligandrum, induces systemic resistance to Fusarium crown and root rot in tomato plants. Plant Physiol Biochem 39:681-696

Bessey EA (1942) Some problems in fungus phylogeny. Mycol Helv 34:355-379

Bilodeau GJ, Lévesque CA, de Cock AWAM, Duchaine C, Brière S, Uribe P, Martin FN, Hamelin RC (2007) Molecular detection of Phytophthora ramorum by RT-PCR using TaqMan, SYBR ${ }^{\circledR}$ Green and Molecular Beacons. Phytopathology 97:633-642

Birch PR, Rehmany AP, Pritchard L, Kamoun S, Beynon JL (2006) Trafficking arms: oomycete effectors enter host plant cells. Trends Microbiol 14:8-11

Blair JE, Coffey MD, Park SY, Geiser DM, Kang S (2008) A multilocus phylogeny for Phytophthora utilizing markers derived from complete genome sequences. Fungal Genet Biol 45:266-277. doi:10.1016/j.fgb.2007.10.010

Brasier CM (2000) The role of Phytophthora pathogens in forests and semi-natural communities in Europe and Africa. In: Hansen EM, Sutton W (eds) Phytophthora Diseases of Forest Trees, Proceedings of the First Meeting of the International Union of Forest Research Organizations (IUFRO). Forest Research Laboratory, Oregon State University, Corvallis, pp 101-115

Brasier CM (2008) How many Phytophthora species? In: 3rd International Phytophthora, Pythium and related genera Workshop, Turin, Italy, 23-24 August 2008. www.phytophthoradb.org/ pdf/O1Brasier.pdf

Brasier CM (2009) Phytophthora biodiversity: how many Phytophthora species are there? In: Goheen EM, Frankel SJ (eds) Phytophthoras in Forests and Natural Ecosystems, Proceedings of the Fourth Meeting of the International Union of Forest Research Organizations (IUFRO). USDA Forest Service, Albany, pp 101-115

Brasier CM, Cooke DEL, Duncan JM (1999) Origin of a new Phytophthora pathogen through interspecific hybridization. Proc Natl Acad Sci U S A 96:5878-5883. doi:10.1073/pnas.96.10.5878

Briard M, Dutertre M, Rouxel F, Brygoo Y (1995) Ribosomal RNA sequence divergence within the Pythiaceae. Mycol Res 99:1119-1127

Cahill DM, Hardham AR (1994) A dipstick immunoassay for the specific detection of Phytophthora cinnamomi in soils. Phytopathology 84:1284-1292
Cavalier-Smith T (1981) From eukaryotic kingdoms: seven or nine? Biosystems 10:93-116

Cavalier-Smith T (1986) The kingdom Chromista: origin and systematics. In: Round FE, Chapman DJ (eds) Progress in phycological research, vol. 4. BioPress Ltd, Bristol, pp 309-347

Cavalier-Smith T (1987) The origin of fungi and pseudofungi. In: Rayner ADM, Brasier CM, Moore D (eds) Evolutionary biology of the fungi. Cambridge University Press, Cambridge, pp 339353

Cavalier-Smith T, Chao E (2006) Phylogeny and megasystematics of phagotrophic heterokonts (Kingdom Chromista). J Mol Evol 62:388-420

Chong J, Barr DJS (1973) Zoospore development and fine structures in Phlyctochytrium arcticum chytridiales. Can J Bot 51:14111420

Cook RJ, Sitton JW, Haglund WA (1987) Influence of soil treatments on growth and yield of wheat and implications for control of Pythium root rot. Phytopathology 77:1192-1198

Cooke DEL, Lees AK (2004) Markers, old and new, for examining Phytophthora infestans diversity. Plant Pathology 53:692-704

Cooke DEL, Drenth A, Duncan JM, Wagels G, Brasier CM (2000) A molecular phylogeny of Phytophthora and related oomycetes. Fungal Genet Biol 30:17-32

De Cock AW, Mendoza L, Padhye AA, Ajello L, Kaufman L (1987) Pythium insidiosum sp. nov., the etiologic agent of pythiosis. J Clin Microbiol 25:344-349

Dick MW (1990) Keys to Pythium. M. W. Dick, Reading

Dick MW (2001) Straminipilous Fungi: systematics of the Peronosporomycetes including accounts of the marine straminipilous protists, the Plasmodiophorids and similar organisms. Kluwer, Dordrecht

Dick MW, Vick MC, Gibbings JG, Hedderson TA, Lopez-Lastra CC (1999) 18S rDNA for species of Leptolegnia and other Peronosporomycetes: justification for the subclass taxa Saprolegniomycetidae and Peronosporomycetidae and division of the Saprolegniaceae sensu lato into the Leptolegniaceae and Saprolegniaceae. Mycol Res 103:1119-1125

Erwin DC, Ribeiro OK (1996) Phytophthora diseases worldwide. American Phytopathological Society, St. Paul

Forbes GA, Goodwin SB, Drenth A, Oyarzun P, Ordonl fez ME, Fry WE (1998) A global marker database for Phytophthora infestans. Plant Dis 82:811-818

Förster H, Kinscherf TG, Leong SA, Maxwell DP (1989) Restriction fragment length polymorphisms of the mitochondrial DNA of Phytophthora megasperma isolated from soybean, alfalfa, and fruit trees. Can J Bot 67:529-537

Förster H, Coffey MD, Elwood H, Sogin ML (1990) Sequence analysis of the small subunit ribosomal RNAs of the three zoosporic fungi and implications for fungal evolution. Mycologia $82: 306-312$

Fry WE, Goodwin SB (1997) Re-emergence of potato and tomato late blight in the United States and Canada. Plant Dis 81:1349-1357

Fry WE, Goodwin SB, Matuszak JM, Spielman LJ, Milgroom MG, Drenth A (1992) Population genetics and intercontinental migrations of Phytophthora infestans. Annu Rev Phytopathol $30: 107-129$

Gäumann E (1923) Beiträge zu einer Monographie der Gattung Peronospora. Beiträge zur Kryptogamenflora der Schweiz 5:1-360

Gavino PD, Smart CD, Sandrock RW, Miller JS, Hamm PB, Lee TY, Davis RM, Fry WE (2000) Implications of sexual reproduction for Phytophthora infestans in the United States: Generation of an aggressive lineage. Plant Dis 84:731-735

Gomez-Alpizar L, Carbone I, Ristaino JB (2007) An Andean origin of Phytophthora infestans inferred from mitochondrial and nuclear gene genealogies. Proc Natl Acad Sci U S A 104:33063311 
Goodwin PH, Kirkpatrick BC, Duniway JM (1989) Cloned DNA probes for identification of Phytophthora parasitica. Phytopathology 79:716-721

Goodwin PH, English JT, Neher DA, Duniway JM, Kirkpatrick BC (1990a) Detection of Phytophthora parasitica from soil and host tissue with a species-specific DNA probe. Phytopathology 80:277-281

Goodwin PH, Kirkpatrick BC, Duniway JM (1990b) Identification of Phytophthora citrophthora with cloned DNA probes. Appl Environ Microbiol 56:669-674

Goodwin SB, Spielman LJ, Matuszak JM, Bergeron SN, Fry WE (1992) Clonal diversity and genetic differentiation of Phytophthora infestans populations in northern and central Mexico. Phytopathology 82:955-961

Goodwin SB, Cohen BA, Fry WE (1994) Panglobal distribution of a single clonal lineage of the Irish potato famine fungus. Proc Natl Acad Sci U S A 91:11591-11595

Green BR, Dick MW (1972) DNA base composition and the taxonomy of the Oomycetes. Can J Microbiol 18:963-968

Grunwald NJ, Flier WG (2005) The biology of Phytophthora infestans at its center of origin. Annu Rev Phytopathol 43:171-190

Grünwald NJ, Goss EM, Ivors K, Garbelotto M, Martin FN, Prospero S, Hansen E, Bonants PJM, Hamelin RC, Chastagner G, Werres S, Rizzo DM, Abad G, Beales P, Bilodeau GJ, Blomquist CL, Brasier C, Brière SC, Chandelier A, Davidson JM, Denman S, Elliott M, Frankel SJ, Goheen EM, de Gruyter H, Heungens K, James D, Kanaskie A, McWilliams MG, Man in 't Veld W, Moralejo E, Osterbauer NK, Palm ME, Parke JL, Sierra AMP, Shamoun SF, Shishkoff N, Tooley PW, Vettraino AM, Webber J, Widmer TL (2009) Standardizing the nomenclature for clonal lineages of the sudden oak death pathogen, Phytophthora ramorum. Phytopathology 99:792-795. doi:10.1094/PHYTO-99-7-0792

Gunderson JH, Elwood H, Ingold A, Kindle K, Sogin ML (1987) Phylogenetic relationships between chlorophytes, chrysophytes, and oomycetes. Proc Natl Acad Sci U S A 84:5823-5827

Haas BJ, Kamoun S, Zody MC, Jiang RHY, Handsaker RE, Cano LM, Grabherr M, Kodira CD, Raffaele S, Torto-Alalibo T, Bozkurt TO, Ah-Fong AMV, Alvarado L, Anderson VL, Armstrong MR, Avrova A, Baxter L, Beynon J, Boevink PC, Bollmann SR, Bos JIB, Bulone V, Cai G, Cakir C, Carrington JC, Chawner M, Conti L, Costanzo S, Ewan R, Fahlgren N, Fischbach MA, Fugelstad J, Gilroy EM, Gnerre S, Green PJ, Grenville-Briggs LJ, Griffith J, Grünwald NJ, Horn K, Horner NR, Hu C-H, Huitema E, Jeong D-H, Jones AME, Jones JDG, Jones RW, Karlsson EK, Kunjeti SG, Lamour K, Liu Z, Ma L, MacLean D, Chibucos MC, McDonald H, McWalters J, Meijer HJG, Morgan W, Morris PF, Munro CA, O'Neill K, OspinaGiraldo M, Pinzón A, Pritchard L, Ramsahoye B, Ren Q, Restrepo S, Roy S, Sadanandom A, Savidor A, Schornack S, Schwartz DC, Schumann UD, Schwessinger B, Seyer L, Sharpe T, Silvar C, Song J, Studholme DJ, Sykes S, Thines M, van de Vondervoort PJI, Phuntumart V, Wawra S, Weide R, Win J, Young C, Zhou S, Fry W, Meyers BC, van West P, Ristaino J, Govers F, Birch PRJ, Whisson SC, Judelson HS, Nusbaum C (2009) Genome sequence and analysis of the Irish potato famine pathogen Phytophthora infestans. Nature 461:393-398

Harvey P, Lawrence L (2008) Managing Pythium root disease complexes to improve productivity of crop rotations. Outlooks on Pest Management 19:127-129

Hayden K, Ivors K, Wilkinson C, Garbelotto M (2006) TaqMan chemistry for Phytophthora ramorum detection and quantification, with a comparison of diagnostic methods. Phytopathology 96:846-854

Holloway SA, Heath IB (1977) An ultrastructural analysis of the changes in organelle arrangement and structure between the various spore types of Saprolegnia sp. Can J Bot 55:1328-1339

Hudspeth DSS, Nadler SA, Hudspeth MES (2000) A COX2 molecular phylogeny of the Peronosporomycetes. Mycologia 92:674-684
Hughes KJD, Tomlinson JA, Griffin RL, Boonham N, Inman AJ, Lane CR (2006) Development of a one-step real-time polymerase chain reaction assay for diagnosis of Phytophthora ramorum. Phytopathology 96:975-981

Hulbert SH, Ilott TW, Legg EJ, Lincoln SE, Lander ES, Michelmore RW (1988) Genetic analysis of the fungus, Bremia lactucae, using restriction fragment length polymorphisms. Genetics 120:947-958

Hulvey J, Telle S, Nigrelli L, Lamour K, Thines M (2010) Salisapiliaceae - a new family of oomycetes from marsh grass litter of southeastern North America. Persoonia 25:109-116

Judelson HS, Michelmore RW (1989) Structure and expression of a gene encoding heat-shock protein Hsp70 from the Oomycete fungus Bremia lactucae. Gene 79:207-217

Judelson HS, Michelmore RW (1990) Highly abundant and stagespecific mRNAs in the obligate pathogen Bremia lactucae. Mol Plant Microbe Interact 3:225-232

Judelson HS, Tyler BM, Michelmore RW (1991) Transformation of the oomycete pathogen, Phytophthora infestans. Mol Plant Microbe Interact 4:602-607

Julich S, Riedel M, Kielpinski M, Urban M, Kretschmer R, Wagner S, Fritzsche W, Henkel T, Möller R, Werres S (2011) Development of a lab-on-a-chip device for diagnosis of plant pathogens. Biosens Bioelectron 26:4070-4075. doi:10.1016/j.bios.2011.03.035

Kamoun S, Huitema E, Vleeshouwers VGAA (1999) Resistance to oomycetes: a general role for the hypersensitive response? Trends Plant Sci 4:196-200. doi:10.1016/s1360-1385(99)01404-1

Kirk PM, Cannon PF, Minter DW, Stalpers JA (2008) Ainsworth and Bisby's dictionary of the fungi, 10th edn. CABI, Wallingford

Klassen GR, McNabb SA, Dick MW (1987) Comparison of physical maps of ribosomal DNA repeating units in Pythium, Phytophthora and Apodachlya. J Gen Microbiol 133:2953-2959

Kox LFF, Van Brouwershaven IR, Van De Vossenberg BTLH, Van Den Beld HE, Bonants PJM, De Gruyter J (2007) Diagnostic values and utility of immunological, morphological, and molecular methods for in planta detection of Phytophthora ramorum. Phytopathology 97:1119-1129

Kroon LPNM, Bakker FT, van den Bosch GBM, Bonants PJM, Flier WG (2004) Phylogenetic analysis of Phytophthora species based on mitochondrial and nuclear DNA sequences. Fungal Genet Biol 41:766-782

Kuepper FC, Maier I, Mueller DG, Goer SL-D, Guillou L (2006) Phylogenetic affinities of two eukaryotic pathogens of marine macroalgae, Eurychasma dicksonii (Wright) Magnus and Chytridium polysiphoniae Cohn. Cryptogamie Algologie 27:165-184

Lamour K, Kamoun S (2009) Oomycete genetics and genomics. Wiley, Hoboken

Leclerc MC, Guillot J, Deville M (2000) Taxonomic and phylogenetic analysis of Saprolegniaceae (Oomycetes) inferred from LSU rDNA and ITS sequence comparisons. Antonie Van Leeuwenhoek 77:369-377

Lee SB, Taylor JW (1992) Phylogeny of five fungus-like protoctistan Phytophthora spp., inferred from the internal transcribed spacers of ribosomal DNA. Mol Biol Evol 9:636-653

Lee TY, Mizubuti E, Fry WE (1999) Genetics of metalaxyl resistance in Phytophthora infestans. Fungal Genet Biol 26:118-130

LéJohn HB (1971) Enzyme regulation, lysine pathways and cell wall structures as indicators of major lines of evolution in fungi. Nature 231:164-168

Lévesque CA, de Cock AWAM (2004) Molecular phylogeny and taxonomy of the genus Pythium. Mycol Res 108:1363-1383

Lévesque CA, Harlton CE, de Cock AWAM (1998) Identification of some oomycetes by reverse dot blot hybridization. Phytopathology $88: 213-222$

Lévesque CA, Brouwer H, Cano L, Hamilton JP, Holt C, Huitema E, Raffaele S, Robideau GP, Thines M, Win J, Zerillo MM, Beakes GW, Boore JL, Busam D, Dumas B, Ferriera S, Fuerstenberg SI, 
Gachon CM, Gaulin E, Govers F, Grenville-Briggs L, Horner N, Hostetler J, Jiang RH, Johnson J, Krajaejun T, Lin H, Meijer HJ, Moore B, Morris P, Phuntmart V, Puiu D, Shetty J, Stajich JE, Tripathy S, Wawra S, van West P, Whitty BR, Coutinho PM, Henrissat B, Martin F, Thomas PD, Tyler BM, De Vries RP, Kamoun S, Yandell M, Tisserat N, Buell CR (2010) Genome sequence of the necrotrophic plant pathogen Pythium ultimum reveals original pathogenicity mechanisms and effector repertoire. Genome Biology 11(R73):22

Lifshitz R, Dupler M, Elad Y, Baker R (1984) Hyphal interactions between a mycoparasite Pythium nunn and several soil fungi. Can J Microbiol 30:1482-1487

Mao Y, Tyler BM (1991) Genome organization of Phytophthora megasperma f.sp. glycinea. Exp Mycol 15:283-291. doi:10.1016/0147-5975(91)90031-8

Martin FN (1991) Characterization of circular mitochondrial plasmids in three Pythium species. Curr Genet 20:91-97

Martin FN, Kistler HC (1990) Species specific banding patterns of restriction endonuclease digested mitochondrial DNA in the genus Pythium. Exp Mycol 14:32-46

Martin FN, Loper JE (1999) Soilborne plant diseases caused by Pythium spp.: ecology, epidemiology, and prospects for biological control. Crit Rev Plant Sci 18:111-181

Martin FN, Tooley PW (2003) Phylogenetic relationships among Phytophthora species inferred from sequence analysis of mitochondrially encoded cytochrome oxidase I and II genes. Mycologia 95:269-284

Martin RR, James D, Lévesque CA (2000) Impacts of molecular diagnostic technologies on plant disease management. Annu Rev Phytopathol 38:207-239

Martin FN, Tooley PW, Blomquist C (2004) Molecular detection of Phytophthora ramorum, the causal agent of sudden oak death in California, and two additional species commonly recovered from diseased plant material. Phytopathology 94:621-631

Martin FN, Coffey MD, Zeller K, Hamelin RC, Tooley P, Garbelotto M, Hughes KJD, Kubisiak T, Bilodeau GJ, Levy L, Blomquist C, Berger PH (2009) Evaluation of molecular markers for Phytophthora ramorum detection and identification: Testing for specificity using a standardized library of isolates. Phytopathology 99:390-403

Mendoza L (2009) Pythium insidiosum and mamellian hosts. In: Lamour K, Kamoun S (eds) Oomycete genetics and genomics. John Wiley \& Sons, Inc., pp 387-405

Money NP (1998) Why oomycetes have not stopped being fungi. Mycol Res 102:767-768

Mullis KB, Faloona FA (1987) Specific synthesis of DNA in vitro via a polymerase-catalyzed chain reaction. Methods Enzymol $155: 335-350$

Nelson EB, Harman GE, Nash GT (1988) Enhancement of Trichoderma -induced biological control of pythium seed rot and preemergence damping-off of peas. Soil Biol Biochem 20:145-150

Newhook FJ, Waterhouse GM, Stamps DJ (1978) Tabular key to the species of Phytophthora De Bary. Mycological Papers 143:120

Packer A, Clay K (2000) Soil pathogens and spatial patterns of seedling mortality in a temperate tree. Nature 404:278-281

Panabières F, Marais A, Trentin F, Bonnet P, Ricci P (1989) Repetitive DNA polymorphism analysis as a tool for identifying Phytophthora species. Phytopathology 79:1105-1109

Parker BC, Preston RD, Fogg GE (1963) Studies of the structure and chemical composition of the cell walls of Vaucheriaceae and Saprolegniaceae. Proc R Soc Lond, Ser B: Biol Sci 158:435-445. doi: $10.1098 / \mathrm{rspb} .1963 .0056$

Patterson DJ (1989) Stramenopiles: chromophytes from a protistan perspective. In: Green JC, Leadbeater BSC, Diver W (eds) The chromophyte algae: problems and perspectives. Clarendon, Oxford, pp 357-379
Paulitz TC, Bélanger RR (2001) Biological control in greenhouse systems. vol 39

Petersen AB, Rosendahl S (2000) Phylogeny of the Peronosporomycetes (Oomycota) based on partial sequences of the large ribosomal subunit (LSU rDNA). Mycol Res 104:1295-1303

Pringsheim N (1858) Beiträge zur Morphologie and Systematik der Algen. 2. Die Saprolegnieen. Jahrbücher für wissenschaftliche Botanik 1:284-306

Rehmany AP, Gordon A, Rose LE, Allen RL, Armstrong MR, Whisson SC, Kamoun S, Tyler BM, Birch PRJ, Beynon JL (2005) Differential recognition of highly divergent downy mildew avirulence gene alleles by RPP1 resistance genes from two Arabidopsis Lines. The Plant Cell Online 17:1839-1850. doi:10.1105/tpc. 105.031807

Reinhart KO, Tytgat T, Van der Putten WH, Clay K (2010) Virulence of soil-borne pathogens and invasion by Prunus serotina. New Phytol (online release, 21 January)

Riethmüller A, Weiß M, Oberwinkler F (1999) Phylogenetic studies of Saprolegniomycetidae and related groups based on nuclear large subunit ribosomal DNA sequences. Can J Bot 77:1790-1800

Riethmüller A, Voglmayr H, Goker M, Weiß M, Oberwinkler F (2002) Phylogenetic relationships of the downy mildews (Peronosporales) and related groups based on nuclear large subunit ribosomal DNA sequences. Mycologia 94:834-849

Rizzo DM, Garbelotto M, Davidson JM, Slaughter GW, Koike ST (2002) Phytophthora ramorum as the cause of extensive mortality of Quercus spp and Lithocarpus densiflorus in California. Plant Dis 86:205-214

Robideau GP, de Cock AWAM, Coffey MD, Voglmayr H, Brouwer H, Bala K, Chitty DW, Désaulniers N, Eggertson QA, Gachon CMM, Hu C-H, Küpper FC, Rintoul TL, SarhanEhab, Verstappen ECP, Zhang Y, Bonants PJM, Ristaino JB, Lévesque CA (2011) DNA barcoding of oomycetes with cytochrome $\mathrm{c}$ oxidase subunit I (COI) and internal transcribed spacer (ITS). Molecular Ecology Resources (in press)

Schurko AM, Mendoza L, Lévesque CA, Desaulniers NL, de Cock AW, Klassen GR (2003) A molecular phylogeny of Pythium insidiosum. Mycol Res 107:537-544

Sekimoto S, Beakes GW, Gachon CM, Muller DG, Kupper FC, Honda D (2008a) The development, ultrastructural cytology, and molecular phylogeny of the basal oomycete Eurychasma dicksonii, infecting the filamentous phaeophyte algae Ectocarpus siliculosus and Pylaiella littoralis. Protist 159:299-318. doi:10.1016/j.protis.2007.11.004

Sekimoto S, Yokoo K, Kawamura Y, Honda D (2008b) Taxonomy, molecular phylogeny, and ultrastructural morphology of Olpidiopsis porphyrae sp. nov. (Oomycetes, straminipiles), a unicellular obligate endoparasite of Bangia and Porphyra spp. (Bangiales, Rhodophyta). Mycol Res 112:361-374. doi:10.1016/j.mycres.2007.11.002

Seymour RL (1970) The genus Saprolegnia. Nova Hedwigia 19:1124

Sparrow FK (1976) The present status of classification in biflagellate fungi. In: Gareth-Jones EB (ed) Recent advances in aquatic mycology. Wiley, NY, pp 213-222

Spies CF, Mazzola M, Botha WJ, Langenhoven S, Mostert L, McLeod A (2011) Molecular analyses of Pythium irregulare isolates from grapevines in South Africa suggest that this species complex may be a single variable species. Fungal Biol (in press)

Tambong JT, de Cock AW, Tinker NA, Lévesque CA (2006) Oligonucleotide array for identification and detection of Pythium species. Appl Environ Microbiol 72:2691-2706

Taylor JW, Jacobson DJ, Kroken S, Kasuga T, Geiser DM, Hibbett DS, Fisher MC (2000) Phylogenetic species recognition and species concepts in fungi. Fungal Genet Biol 31:21-32 
Thines M, Goeker M, Telle S, Ryley M, Mathur K, Narayana YD, Spring O, Thakur RP (2008) Phylogenetic relationships of graminicolous downy mildews based on cox2 sequence data. Mycol Res 112:345-351. doi:10.1016/j.mycres.2007.10.010

Thomas PA (2003) Current perspectives on ophthalmic mycoses. Clin Microbiol Rev 16:730-797. doi:10.1128/cmr.16.4.730-797.2003

Tomlinson JA, Barker I, Boonham N (2007) Faster, simpler, morespecific methods for improved molecular detection of Phytophthora ramorum in the field. Appl Environ Microbiol 73:4040-4047

Tooley PW, Martin FN, Carras MM, Frederick RD (2006) Real-time fluorescent polymerase chain reaction detection of Phytophthora ramorum and Phytophthora pseudosyringae using mitochondrial gene regions. Phytopathology 96:336-345

Tsui CKM, Marshall W, Yokoyama R, Honda D, Lippmeier JC, Craven KD, Peterson PD, Berbee ML (2009) Labyrinthulomycetes phylogeny and its implications for the evolutionary loss of chloroplasts and gain of ectoplasmic gliding. Mol Phylogenet Evol 50:129-140. doi:10.1016/j.ympev.2008.09.027

Tyler BM, Tripathy S, Zhang X, Dehal P, Jiang RH, Aerts A, Arredondo FD, Baxter L, Bensasson D, Beynon JL, Chapman J, Damasceno CM, Dorrance AE, Dou D, Dickerman AW, Dubchak IL, Garbelotto M, Gijzen M, Gordon SG, Govers F, Grunwald NJ, Huang W, Ivors KL, Jones RW, Kamoun S, Krampis K, Lamour KH, Lee MK, McDonald WH, Medina M, Meijer HJ, Nordberg EK, Maclean DJ, Ospina-Giraldo MD, Morris PF, Phuntumart V, Putnam NH, Rash S, Rose JK, Sakihama Y, Salamov AA, Savidor A, Scheuring CF, Smith BM, Sobral BW, Terry A, Torto-Alalibo TA, Win J, Xu Z, Zhang H, Grigoriev IV, Rokhsar DS, Boore JL (2006) Phytophthora genome sequences uncover evolutionary origins and mechanisms of pathogenesis. Science 313:1261-1266

van der Plaats-Niterink AJ (1981) Monograph of the genus Pythium. Stud Mycol 21:1-242
Vesely D (1977) Potential biological control of damping-off pathogens in emerging sugar beet by Pythium oligandrum. Phytopathologische Zeitschrift 90:113-115

Vogel HJ (1960) Two modes of lysine synthesis among lower fungi: evolutionary significance. BBA - Biochimica et Biophysica Acta 41:172-173

Vogel HJ (1961) Lysine synthesis and phytogeny of lower fungi: some chytrids versus Hyphochytrium. Nature 189:1026-1027

Voglmayr H (2003) Phylogenetic relationships of Peronospora and related genera based on nuclear ribosomal ITS sequences. Mycol Res 107:1132-1142

Waterhouse GM (1963) Key to the species of Phytophthora de Bary. Mycological Papers 92:1-22

Waterhouse GM (1967) Key to Pythium Pringsheim. Mycological Paper No. 109. Kew, Surrey, England: Commonwealth Mycological Institute

Werres S, Marwitz R, Man In'T Veld WA, De Cock AWAM, Bonants PJM, De Weerdt M, Themann K, Ilieva E, Baayen RP (2001) Phytophthora ramorum sp. nov., a new pathogen on Rhododendron and Viburnum. Mycol Res 105:1155-1165

Whisson SC, Boevink PC, Moleleki L, Avrova AO, Morales JG, Gilroy EM, Armstrong MR, Grouffaud S, van West P, Chapman S, Hein I, Toth IK, Pritchard L, Birch PRJ (2007) A translocation signal for delivery of oomycete effector proteins into host plant cells. Nature 450:115-118

White TJ, Bruns T, Lee S, Taylor J (1990) Amplification and direct sequencing of fungal ribosomal RNA genes for phylogenetics. In: Innis MA, Gelfand DH, Sninsky JJ, White TJ (eds) PCR Protocols, a guide to methods and applications. Academic, San Diego, pp 315-322

Winter G (1880) Rabenhorst's Kryptogamen-Flora, Pilze - Schizomyceten, Saccharomyceten und Basidiomyceten, vol 1. 2nd edn 